\title{
Култура и Агенда одрживог развоја 2030
}

\author{
Христина Микић \\ Институт за креативно предузетништво и иновације, Београд \\ info@kreativnaekonomija.com
}

\begin{abstract}
Сажетак
Интересовање теоретичара и практичара за однос културе и одрживог развоја актуелан је у последњих неколико година, нарочито од краја 2015. године, када су Уједињене нације усвојиле Агенду одрживог развоја до 2030. Њоме се програмирају глобални циљеви развоја и преиспитују изазови који стоје на путу унапређења развојних процеса. Овај рад бави се улогом културе у остваривању циљева одрживог развоја до 2030. године. У уводним разматрањима, даје се оквир за анализу културе и одрживог развоја. Други део рада посвећен је ретроспективи активности Уједињених нација у пољу културе. Последњи део рада анализира улогу библиотека у остваривању Агенде одрживог развоја 2030.
\end{abstract}

Кључне речи: култура, Уједињене нације, одрживи развој, библиотеке, Агенда 2030, UNESCO

\section{Увод}

Повећано интересовање теоретичара и практичара за питања одрживог развоја појављује се након публиковања извештаја о одрживом развоју који је, на позив Уједињених нација, сачинила Светска комисија за заштиту животне средине и развој 1987. године. ${ }^{1}$ Одрживи развој дефинисан је у светлу економског раста који је у функцији људског развоја, проширивања избора и могућности појединаца, као „развој којим се могу задовољити потребе садашњице, а да се не доводи у питање способност будућих генерација да задовоље властите потребе." ${ }^{2}$ Питања одрживог развоја првенствено су била посвећена очувању разноликости природне средине и еколошким питањима, да би тек касније и култура добила своје место. Наиме, интегрални приступ који се промовисао кроз концепт одрживог развоја означио је укључивање економске, технолошке, социјалне, еколошке и културне компоненте у развојне процесе, са идејом да се једино на тај начин може успоставити функционална равнотежа на релацији производње и потрошње ресурса. ${ }^{3}$ Велики број аутора од тада до данас покушао је да пружи допринос бољој концептуализацији културе у контексту одрживог развоја, али је ипак и даље видљива дискрепанција између теоријских разматрања и практичног укључивања културе у политике одрживог развоја. ${ }^{4}$ Она је углавном условљена сложеношћу појма култура и одрживост, стога допушта многострука и различита тумачења, у зависности од историјског, друштвеног и културног контекста.

Стручњаци окупљени око Уједињених нација питањима одрживог развоја приступају из перспективе смањења сиромаштва, одрживости природних и културних ресурса, једнаког

\footnotetext{
${ }^{1}$ UN World Commission on Environment and Development, Report on the World Commission on Environment and Development: Our Common Future (New York: United Nations -World Commission on Environment and Development, 1987), preuzeto 1. 7. 2018, http://www.undocuments.net/our-common-future.pdf.

2 Ibidem.

${ }^{3}$ Видети више: Х. Микић, „Економске претпоставке и развојни ефекти креативног сектора националне привреде“ (докторска дис., Економски факултет, 2016), 42-52.

${ }^{4}$ D. Throsby, Economics and Culture (Cambridge: Cambridge University Press, 2011), 65; D. Throsby, “Culture in Sustainable Development: Insights for the Future Implementation of Art 13", preuzeto 5. 7. 2018, http://unesdoc.unesco.org/images/0015/001572/157287E.pdf.
} 
приступа основним ресурсима у образовању, култури, здравству... као и остваривања права на достојанствен живот. С друге стране, теоретичари одрживог развоја примарно се баве теоријским концептима и димензијама одрживог развоја. Култура као димензија одрживог развоја оправдана је чињеницом да обликује развојне процесе, као и културне обрасце и понашања људи. ${ }^{5}$ Ово схватање усмеравало је истраживачке напоре углавном ка елаборирању улоге културе као четвртог стуба одрживог развоја. Међутим, у новије време може се запазити тренд у коме се, наместо културе као димензије одрживог развоја, све више помиње појам „култура одрживости“. Она представља позитивне промене које развој културног сектора уноси у потрошњу и производњу, стварање нових навика одрживог коришћења ресурса и изградњу свести код људи о ограничењима и ризицима који могу настати неодговорном потрошњом. ${ }^{6}$

\section{Уједињене нације и култура}

Основане након Другог светског рата, Уједињене нације имају дугу историју интегрисања културе у своје активности и програме. Активности у овој области започињу доношењем Универзалне декларације о људским правима7 у којој се о култури промишља у духу индивидуалних права сваког појединца, достојанственог живота и слободног развоја личности, а ове идеје даље се разрађују у Међународном пакту о економским, социјалним и културним правима. ${ }^{8}$ Данас је то глобални стандард за људска права и, према овом међународном споразуму, државе чланице УН обавезују се да сваком појединцу гарантују остваривање културних права - да учествује у културном животу, да се користи достигнућима науке и ужива морална и материјална права која проистичу из ауторских дела. Напредак држава у остваривању ових права прати се периодичним евалуацијама које спроводи Комитет за економска, социјална и културна права при Уједињеним нацијама, дају се препоруке и изражава забринутост у случају слабог напретка у овој области. ${ }^{9}$

Остале активности на плану интегрисања културе у рад Уједињених нација спроводе се, у различитом опсегу, кроз 15 агенција и неколико програма. Организација Уједињних нација за образовање, културу и науку и Светска организација за интелектуалну својину, кроз рад агенција, баве се директно питањима културе. Прва од њих, своју културну мисију остварује кроз програме којима се обезбеђују заштита и унапређење културне разноликости, право на слободу и уметничко изражавање, циркулација културних добара и услуга и приступ културним садржајима. Друга своју мисију у пољу културе остварује кроз програм заштите ауторских и сродних права уметника, стваралаца и културних радника, као и права интелектуалне својине у сфери материјалног и нематеријалног културног наслеђа.

Уједињене нације су се, до средине деведесетих година 20. века, претежно бавиле питањима културе кроз перспективу индивидуалних културних права појединаца. Педесетогодишњи период обележен је темама које су се кретале од права на слободу изражавања и стваралаштва, интеркултурални дијалог, укидање цензуре и прогона уметника, до бољег приступа

\footnotetext{
${ }^{5}$ UCLG, "Culture: Fourth Pillar of Sustainable Development",Committee on Culture for 2011-2013, preuzeto 1. 7. 2018, http://www.agenda21culture.net/docs_circulars/ECOSOC2013-Committeeonculture-ENG.pdf.

${ }^{6}$ A. Opaku, "The Role of Culture in a Sustainable Built Environment", in Sustainable Operations Management, edited by A. Chiarini (Cham: Springer, 2015), 37-52.

7 УН, Универзална декларација о људским правима (УН, 1948).

8 УН Генерана скупштина, Међунароgни йакй о економским, социјалним и кулйурним иравима (УН Генерална скупштина, 1966), преузето 1. 7. 2018, http://www.unmikonline.org/regulations/unmikgazette/05bosniak/BIntCovEcSocCulRights.pdf.

9 Последњи извештај који је поднела наша земља датира из 2014. године, где је изражена забринутост у погледу једнаког приступа култури, нарочито у руралним подручјима земље, услова за остваривање културних права националих мањина (нарочито Бошњака) и низак ниво финансирања културе. Види: УН Економски и социјални савет, Закључне ӣримеgбе о gруїом иеериоgичном извешйају Србије (УН Економски и социјални савет, 23. мај 2014), преузето 1. 7. 2018, http://www.rwfund.org/wp-content/uploads/2014/12/ Ekonomski-i-socijalni-savet-UN-Komitet-za-ekonomska-socijalna-i-kulturna-prava.pdf.
} 
културним садржајима и слично. Тек објављивањем извештаја Светске комисије за културу под називом „Наша креативна разноликост ${ }^{\prime 10}$ и публиковањем два глобална извештаја о култури ${ }^{11}$ тежи се интегрисању културе у процесе одрживог развоја. Разна саопштења и декларације који ће уследити, сваки на свој начин, утирали су пут једној новој глобалној парадигми - разумевању и прихватању културе као једног од стубова одрживог развоја. Ови догађаји текли су упоредо са припремним процесом креирања Миленијумских циљева развоја Уједињених нација до 2015. године. На светском самиту Уједињених нација 2000. године потписана је Миленијумска декларација као израз настојања земаља чланица УН ка стварању праведнијег друштва, смањењу сиромаштва и остваривању људских права. ${ }^{12}$ Након консултација са државама чланицама Уједињених нација, 2005. године усвојени су Миленијумски циљеви развоја. Они садрже 8 поглавља (смањење екстремног сиромаштва и глади, једнак приступ основном образовању, промовисање родне равноправности и оснаживања жена, смањење смрти новорођенчади, унапређење здравља, сузбијање ХИВ-а, маларије и осталих болести, обезбеђивање еколошке одрживости, развој глобалног партнерства за развој), 16 оперативних циљева и 60 техничких индикатора. Мада је било покушаја да се кроз јавне кампање култура укључи као 9. миленијумски циљ, ${ }^{13}$ такви напори нису имали позитивне исходе.

Култура се у Миленијумским циљевима развоја спомиње у врло апстрактном маниру, у оквиру оперативног циља посвећеног искорењивању екстремног сиромаштва и глади. Она сама по себи није циљ, већ инструмент за постизање одређених развојних резултата. Наиме, јачање креативних индустрија и заштита природног и културног наслеђа сматрају се ефикасним инструментима економског развоја и унапређења квалитета живота сваког појединца. Стварањем предуслова за развој креативног сектора креирају се нове могућности за запошљавање и смањење сиромаштва и доприноси укључивању различитих (често маргиналних и рањивих) група у друштвени, културни и политички живот. У извештајима о реализацији Миленијумских циљева, о култури се углавном промишља као средству подстицања одрживог развоја на афричком континенту и у регионима карактеристичним по екстремном сиромаштву. Поједини аутори посебно истичу улогу библиотека, чија друштвена мисија је у потпуности компатибилна са филозофијом Миленијумских циљева. Тако, на пример, анализирајући улогу школских и јавних библиотека у неразвијеним земљама, Кролак истиче да библиотеке играју важну улогу у приступу информацијама и образовним материјалима, унапређењу образовних достигнућа младих и да представљају важне снаге друштвених промена и демократске реконструкције цивилног друштва. ${ }^{14}$ Поједини аутори наводе да библиотеке могу помоћи смањењу сиромаштва кроз пружање релевантних информација сиромашном становништву, као и подизањем јавне свести о овим проблемима, ${ }^{15}$ други пак улогу библиотека у остваривању Миленијумских циљева виде у систематизацији информација и материјала који су приступачни члановима локалних заједница и прилагођени специфичним образовним потребама локалног становништва. ${ }^{16}$ У оснаживању жена и унапређењу родне равноправности,

${ }^{10}$ UNESCO, Our Creative Diversity (Paris: UNESCO, 1996), preuzeto 1. 7. 2018, http://unesdoc.unesco.org/images/0010/001055/105586e. pdf.

${ }^{11}$ Видети: UNESCO, Culture, Creativity and Markets (Paris: UNESCO, 1998); UNESCO, Cultural Diversity, Conflicts and Pluralism (Paris: UNESCO, 2000)

12 UN, "United Nations Millennium Declaration", 55/2 (United Nations, 2000), preuzeto 1. 7. 2018, https://www.un.org/millennium/ declaration/ares552e.htm.

${ }^{13}$ Кампања је покренута на конференцији Beyond Diversity Хуманистичког института за развојну сарадњу 2005. године. Сматрало се да је култура есенцијални елемент друштвеног развој те да би креативност и креативни потенцијал заједница требало да буду препознати у развојним процесима, попут Миленијумских циљева развоја.

${ }^{14}$ L. Krolak, "The Role of Libraries in the Creation of Literate Environments" (IFLA, 2005), preuzeto 1. 7. 2018, https://www.ifla.org/ files/assets/literacy-and-reading/publications/role-of-libraries-in-creation-of-literate-environments.pdf.

${ }^{15}$ E. Forsyth, "Public Libraries and the Millennium Development Goals", IFLA Journal 31, 4 (2005): 315-323.

${ }^{16}$ Види: А. Uhegbu and I. Igwe, "Information and Communication Technology (I.C.T) and the Millennium Development Goals", Information Technologist 3: 2 (2006): 97-109; Krolak, Nav. delo. 
библиотеке такође могу наћи своје место. У њима је омогућен приступ знању и новим вештинама, као и информацијама које су родно сензитивне, што има важан утицај на оснаживање жена. ${ }^{17}$ У многим неразвијеним земљама библиотеке могу бити фокалне тачке за промовисање принципа одрживог развој и унапређење свести о еколошким ресурсима, њиховом очувању, али и ризицима деградације. ${ }^{18}$

Како би питању културе био дат већи значај, Уједињене нације су, у периоду од 2003. до 2015. године, усвојиле три резолуције о култури и развоју. ${ }^{19}$ Са циљем да се дају смернице за укључивање културе у имплементацију Миленијумских циљева, резолуције су подвукле значај који култура има у њиховом остваривању, њену кључну улогу за одрживи развој, идентитет, иновације и креативност, као и у процесу подстицања економског развоја.

Пред крај оперативног периода за спровођење Миленијумских циљева интензивирано је преиспитивање улоге културе у развоју. На почетку овог процеса формирана је Мрежа за решења одрживог развоја, чији су чланови били угледни међународни стручњаци. Они су предложили 10 циљева одрживог развоја (смањење сиромаштва, одрживи градови и урбанизација, квалитетно образовање, заштита животне средине и климатске промене, полна једнакост и женско оснаживање, социјална инклузија, помирење, економско оснаживање) које би требало остварити до 2030. године. Упоредо са радом Мреже, формирана је и Отворена радна група са 30 представника различитих држава - чланица УН које су се бавиле питањима и уобличавањем циљева одрживог развоја. Партиципативност овог процеса обележена је већим бројем консултација, у које су били укључени грађани. Култура и развој биле су теме националних консултација у Србији и Босни и Херцеговини.

Пут ка финалном предлогу циљева одрживог развоја који су прихватљиви и за развијене и неразвијене земље, обележило је и неколико иницијатива и састанака који су преиспитивали однос културе и одрживог развоја. Први који је био већих размера одржан је у Хангжоу (Кина). На њему је усвојена декларација Култура: кључна за одрживи развој, где је предложено експлицитније укључивање културе у развојне процесе и боље разумевање креативне економије као будућег мотора глобаног економског прогреса. ${ }^{20}$ На 3. Светском форуму о културним и креативним индустријама, међународна заједница упутила је сличне апеле и препоруке. Оне су садржане у Декларацији из Фиренце. ${ }^{21}$ У њој се наводи 13 главних препорука, чија је суштина унапређење јавних политика у правцу њихове боље културне сензитивности, ојачавање правног и политичког окружења које промовише културну разноликост и интегрисање културе у одрживи развој. Током консултативног процеса израде нове Агенде одрживог развоја 2030, мрежа међународних невладиних организација поднела је предлог за експлицитно укључивање културе у развојне циљеве (нпр. да се усвоји посебан циљ посвећен само култури), али овај предлог није наишао на одобравање. 22 Тако је, крајем 2015. године, усвојена је Агенда до 2030. без експлицитног циља искључиво посвећеног култури (осим неколико оперативних циљева), али уз шире виђење њене улоге као инструмента за остваривање већине циљева одрживог развоја.

\footnotetext{
${ }^{17}$ Forsyth, Nav. delo.

18 Krolak, Nav. delo.

${ }_{19}^{19}$ Видети: UN General Assembly, Resolution Adopted by the General Assembly - 57/249. Culture and Development 57/249, (New York: UN, 2003); UN General Assembly, Resolution on Culture and Development A/C.2/65/L.50, (New York: UN, 2010); UN General Assembly, Resolution on Culture and Sustainable Development A/C8/440/add.4, (New York: UN, 2013).

${ }^{20}$ UNESCO, Hangzhou Declaration Placing Culture at the Heart of Sustainable Development Policies (Paris: UNESCO, 2013).

21 UNESCO, Florence Declaration Outlines Recommendations on Culture for Post-2015 Agenda: Culture, Creativity and Sustainable Development Research, Innovation, Opportunities (Florence: UNESCO, 2014).

22 Мрежа организација у области културе попут IFACCA, IFCCD, Agenda 21 for culture (UCLG), Culture Action Europe, Arterial Network, IMC - International Music Council, ICOMOS, IFLA и Latinoamerican Network of Arts for Social Transformation покренуле су глобалну кампању \#culture2015goal са циљем да се специфичан циљ намењен култури укључи у нову агенду одрживог развоја заједно са оперативним циљевима у овој области. Видети: Global Network of Cities, Local and Regional Governments, preuzeto 1. 7. 2018, http://www.agenda21culture.net/advocacy/culture-as-a-goal-in-post-2015.
} 


\section{Улога библиотека у остваривању УН циљева одрживог развоја до 2030. године}

Агенда одрживог развоја до 2030, усвојена крајем 2015. под окриљем Уједињених нација, састоји се од 17 циљева и 169 специфичних активности и резултата који би њеном имплементацијом требало да буду остварени. ${ }^{23}$ Полази се од претпоставке да се синергијским деловањем владиног сектора, цивилног друштва и приватног сектора могу покренути структурне промене у економији и друштву, које ће водити праведнијој расподели ресурса и смањењу јаза између развијених и неразвијених земаља.

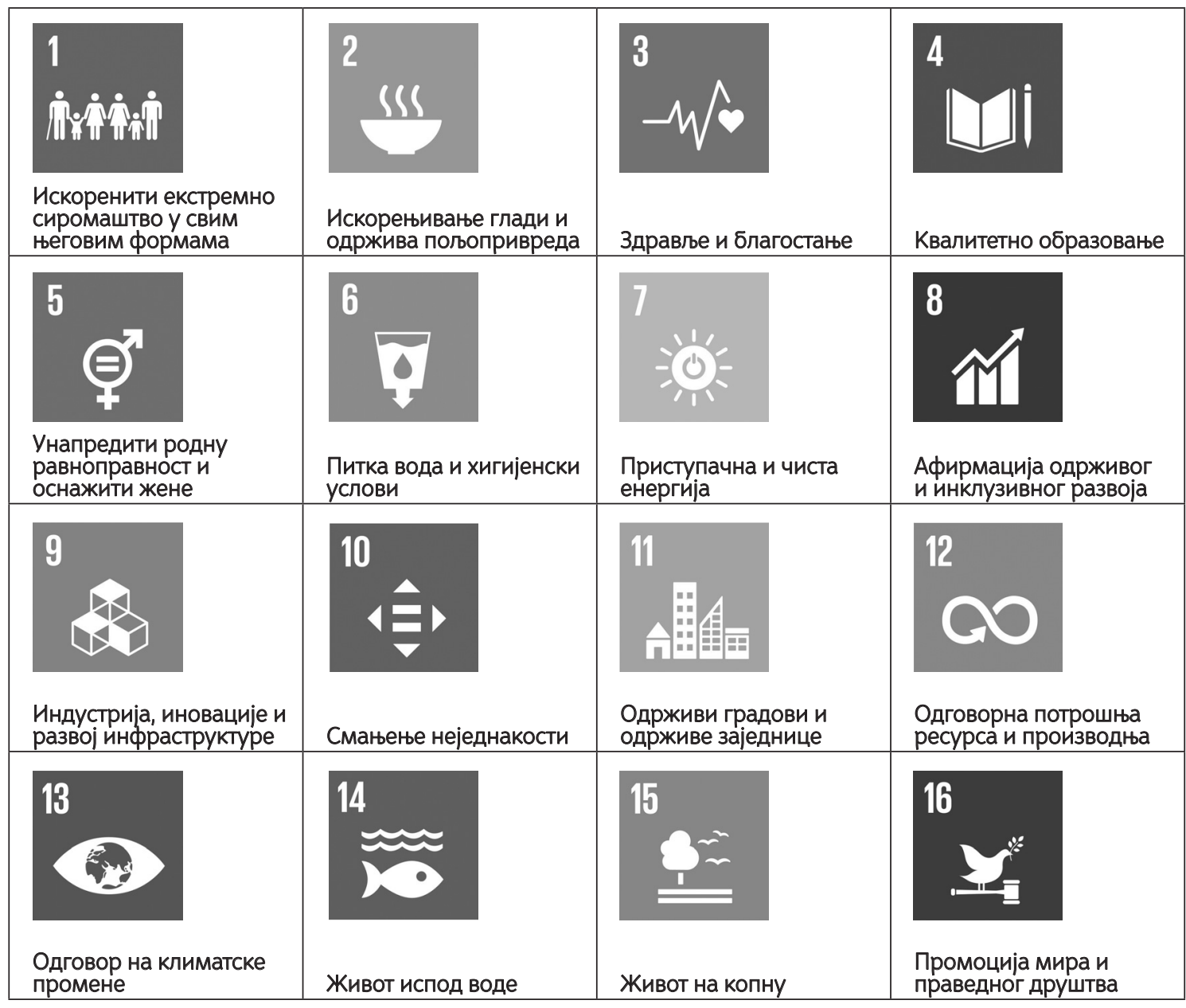

\section{Циљеви Агенде одрживог развоја 203024}

Агенда се експлицитно не бави питањима културе у одрживом развоју. У појединим циљевима, њен допринос се апострофира на пољу образовања и економског оснаживања кроз културни туризам. У уводу овог документа култура се спомиње само у једном параграфу, кроз декларативну потврду значаја природне и културне разноликости и њиховог доприноса и кључне улоге у одрживом развоју. У циљевима о култури се говори као о компоненти образовања које промовише одрживи развој (циљ 4), ресурсу за развој одрживог туризма (циљ 8), градова и

\footnotetext{
${ }^{23}$ UN, Transforming Our World: the 2030 Agenda for Sustainable Development, A/RES/70/1 (New York: UN, 2015).

${ }^{24}$ Инфографике циљева одрживог развоја преузете са SeCons, преузето 1. 7. 2018, http://www.ciljeviodrzivograzvoja.net.
} 
одрживости заједница (циљ 11). Међутим, иако културалисти ${ }^{25}$ с правом истичу слабу заступљеност културе као мањкавост Агенде, уочљиво је да се она у глобалним циљевима одрживог развоја више третира као међусекторска област. Наиме, кроз оперативне смернице за примену Агенде, очитава се да се култури и креативном предузетништву приступа као хоризонталном питању јавних политика, које није ограничено одређеним циљевима, већ представља једну од димензија глобалних развојних процеса.


остваривање основних права на достојанствен живот. На врху лествице УН приоритета налази се подстицање развоја који је инклузиван, уз помоћ кога се могу креирати одржива радна места и подстицати једнакост. Сиромаштвом се сматра живот са мање од 1,25 америчких долара дневно, а да би се оно искоренило, непоходно је кроз јавне политике и друге мере омогућити једнака права на приступ привредним ресурсима, услове за развој предузетништва и креирање нових радних места. Култура ту налази место кроз концепт креативних индустрија и креативног предузетништва, о чему сведочи велики број иницијатива које је реализовао UNESCO. ${ }^{26}$ Библиотеке у остваривању овог циља могу преузети улогу центара за унапређење вештина, дигиталне писмености и приступа информацијама за најугроженије слојеве становништва. На пример, у Кини је пројекат промоције дигиталне библиотеке (Digital Promotion Project) омогућио приступ дигиталним садржајима путем јавних библиотека, јавног интернета и мобилних телефона, како би се унапредио квалитет живота у руралним подручјима ове земље, а у појединим кинеским библиотекама нуде се и тренинзи за стицање дигиталних вештина, асистенција у претраживању дигиталних извора и помоћ за лакше долажење до информација. ${ }^{27}$ у Чилеу, Tolten Public Library пружа програме за развој предузетничких вештина Мапуче народу како би превазишао економске изазове, започео послове у руралном туризму и сл., док остале чилеанске јавне библиотеке спроводе тренинге за унапређење дигиталних вештина становника у забаченим регионима, укључујући и онлајн промоцију њихових предузетничких иницијатива. ${ }^{28}$

Искорењивање їлаgи и одржива йољойривреgа као циљ захтевају повећана улагања у сеоску инфраструктуру и развој пољопривреде. Нематеријално наслеђе у руралним подручјима углавном обухвата традиционална знања, поступке и процесе рада. Његовом заштитом осигуравају се услови за привредни напредак многих руралних подручја. Чак и тамо где није изражен рурални карактер места, организације у култури, попут библиотека, могу имати своју улогу у ширењу принципа одрживе пољопривредне производње те посредно дати допринос искорењивању глади. Тако, на пример, Digital Green је иницијатива која креира и приказује дигиталне видео-садржаје како би помогла одрживу пољопривреду у Јужној Азији и Африци. Коришћењем партиципативних видео-материјала пружају се саветодавне услуге локалним пољопривредницима у руралним подручјима. Пројекат је започео обуком за креирање кратких видео-туторијала за фармере у којима они описују пољопривредне проблеме, демонстрирају решења и њихову примену. Од настанка пројекта произведено је око 2800 кратких видео-материјала за пољопривреднике и дистрибуирано у преко 2000 села у Индији, Гани, Етиопији и Танзанији преко мреже руралних организација у култури и малих сеоских библиотека. ${ }^{29}$

\footnotetext{
25 Заговорници пренаглашене улоге културе у одрживом развоју.

${ }_{26}^{26}$ Видети програме које је спровео UNESCO на тему развој предузетништва и креативних индустрија. UNESCO, Culture for the 2030 Agenda (Paris: UNESCO, 2018), preuzeto 1. 7. 2018, http://unesdoc.unesco.org/images/0026/002646/264687e.pdf; UNESCO. UNESCO Moving Forward the 2030. Agenda for Sustanible Development. (Paris: UNESCO, 2017), preuzeto 1. 7. 2018, http://unesdoc.unesco. org/images/0024/002477/247785e.pdf

27 World Bank, Fostering a Digitally Inclusive Aging Society in China: the Potential of Public Libraries (Washington: World Bank, 2014).

${ }_{28}^{28}$ Видети: U. Lipeikaite and G. Oyarzun, Agriculture, Libraries and Human Development: Case studies of Europe, Africa and Latin America (Singapore: IFLA WLIC, 2013), preuzeto 1. 7. 2018, http://library.ifla.org/115/1/141-lipeikaite-en.pdf.

${ }^{29}$ P. Shan and G. Abhishek, Digital Libraries for the Poor (Washington: World Bank, 2014), preuzeto 1. 7. 2018, http://blogs.worldbank. org/endpovertyinsouthasia/digital-libraries-poor.
} 
Пројекат AgroLib који је реализовала Народна библиотека „Радислав Никчевић“ у Јагодини такође је пример добре праксе како библиотеке могу допринети одрживој пољопривреди. У руралним подручјима у Србији, многе е-информације не долазе до пољопривредника, јер они немају компјутере, нити приступ интернету. Сличан проблем постоји и у дистрибуцији информација које се тичу олакшица и субвенција за пољопривреднике - оне се објављују на веб-страницама државних органа, али тешко стижу до пољопривредника. У многим селима интернет је тешко доступан, а до данас се нико није бавио системски информационим технологијама и њиховим предностима у циљу модернизације сеоског живота. Пољопривредна библиотека намењена је корисницима у 52 села јагодинске општине кроз четири ревитализоване библиотеке - Багрдан, Глоговац, Бунар и Главинци. Осим што је набављена стручна литература за пољопривреднике, реновиране библиотеке, уведен је интернет и формирана електронска пијаца за пољопривреднике и остале становнике из јагодинских села који се баве ручним радом, занатима и другим видовима руралног предузетништва, организоване су обуке за коришћење информационих технологија из области пољопривреде и предузетништва и сеоске библиотеке су постале ново место сусрета и развоја локалне заједнице. ${ }^{30}$

Зgравље и блаїстиање као циљеви одрживог развоја односе се на промовисање здравог живота, искорењивање болести - ХИВ, маларије, туберкулозе и сл. и решавање савремених здравствених проблема. Јавне библиотеке често могу бити места јавног дијалога, где корисници здравствених услуга могу размењивати своја искуства, али и ширити информације које се тичу смањења ризика за појаву ових болести. Неколико јавних библиотека у Боцвани, као што je Ramotswa Public Library, у сарадњи са друштвима за превенцију ХИВ-а, едукују младе људе о здравственим питањима у вези са ХИВ-ом и тинејџерским трудноћама. ${ }^{31}$ Државна библиотека "Gheorghe Asachi“ у Јашију (Румунија), у сарадњи са Црвеним крстом, креирала је онлајн тренинге и дигиталне материјале о првој помоћи, како би даље обучавала запослене у другим библиотекама и чланове локалне заједнице о пружању прве помоћи. ${ }^{32}$

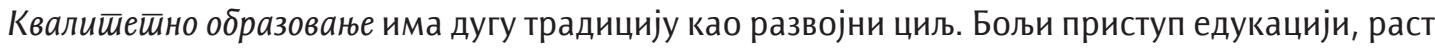
писмености, унапређење образовног нивоа девојчица и сл. предуслови су за боље запошљавање, већи број пословних прилика и развој предузетничких иницијатива. Како би се постигао овај циљ, потребно је омогућити приступачност и услове образовања свим појединцима. Савремене технологије нуде многе могућности да се превазиђу физичка ограничења доступности едукације. У Боцвани, јавне библиотеке су главни носиоци пројекта Национална визија 2016. који је посвећен унапређењу савремених знања и вештина за најширу популацију. ${ }^{33}$ Улога библиотека у повећању квалитета образовања нарочито се види у раду школских библиотека и њиховом укључивању у процесе школовања. Експериментални час, спроведен у основној школи у Бачкој Паланци, показао је да укључивање школске библиотеке у извођење наставе и њено ослањање на информатичку мрежу доприноси бољем усвајању знања код ученика, њиховом осамостаљивању у претраживању информација и општем задовољству код ученика. ${ }^{34}$

Унайређење рояне равнойравностии и оснаживање жена би требало да омогући достојанствен рад, уклањање свих облика дискриминације и једнаку заступљеност жена у процесима политичког и економског развоја. Култура пружа обиље могућности за оснаживање жена. Пре свега, у појединим областима оне представљају главну радну снагу (нпр. ручни радови, дизајн

${ }^{30}$ В. Црнковић, „Сеоске библиотеке у функцији подизања предузетничких капацитета - пример пројекта Пољопривредне библиотеке“, излагање на 2. Школи креативне економије (Ниш: Група за креативну економију, 2016).

31 Ramotswa Public Library, Sesigo Libraries, Botswana, preuzeto 1. 7. 2018, http://www.sesigo.org.bw/index.php?id=49.

32 Видети: S. Fried et al., "A Tale of Public Libraries in Bulgaria, Poland and Romania: The Case of Three Gates Foundation Grants", Library Trends (Fall 2014): 127-143.

${ }_{33}$ IFLA, "The Role of Public Libraries in the Attainment of Botswana's Vision 2016", preuzeto 1. 7. 2018, http://library.ifla.org/258/1/201radijeng-en.pdf.

${ }^{34}$ Видети више: ). Кузмановић, „Нова улога библиотеке у основним школама и комуникациона стратегија за њено промовисање“, Кулйура йолиса бр. 17 (2012): 123-146. 
и сл.), послови у култури пружају им могућност за боље балансирање обавеза на послу и у домаћинству, а кроз флексибилне облике рада могу да унапреде своју економску независност и радом од куће. Улога библиотека у остваривању овог циља је у промовисању родне равноправности и њеном унапређивању кроз образовање, оснаживање и укључивање жена у све аспекте друштвеног, културног, економског и политичког живота. ${ }^{35}$ READ Information and Resource Centre у Непалу спроводи програм за оснаживање жена и подстицај њиховом лидерству кроз семинаре, радионице и јавне трибине. Библиотека, осим едукације у погледу људских права, родне равноправности, здравља, спречавања насиља и сл., пружа им могућност и да унапреде пословне вештине - дигиталну писменост, предузетничке способности, стекну неке креативне вештине за израду рукотворина и реализују предузетничку идеју. ${ }^{36}$

Питика воgа и хиїијенски услови односе се на обезбеђивање једнаког приступа пијаћој води и хигијенским условима. Иако је овај циљ специфичног карактера, често изван домета установа културе, иновативни пример из Хондураса показује да јавне библиотеке могу играти централну улогу у обезбеђивању пијаће воде за локалну заједницу. San Juan Planes Community Library представља централно место за снабдевање водом локалне заједнице. ${ }^{37}$

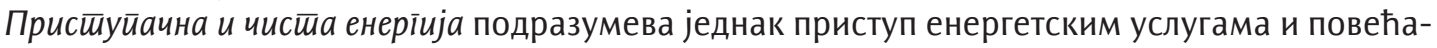
но коришћење обновљивих извора енергије. Очекује се да се главне активности у оквиру овог циља реализују у оквиру иницијативе Оgржива енеріија за све (SE4aLL). У оквиру ње, формирани су центри за техничку помоћ који различитим земљама помажу у креирању ефикасних политика за унапређење коришћења енергије, а кроз директну финансијску помоћ реализују се пројекти у сфери обновљивих извора енергије и повећања енергетске ефикасности, нарочито у руралним областима. Улога библиотека у остваривању овог циља првенствено је усмерена на едукацију локалног становништва о еколошким питањима, одрживом коришћењу природних и културних ресурса и стварању нових знања и навика по питању енергетске ефикасности. На пример, у Гвајани Yupukari Public Library помаже локалном становништу да стекне знања и лакше усвоји принципе за постизање еколошке равнотеже. Библиотека представља место где се састају чланови локалне заједнице и невладине организације и размењују искуства о заштити корњача и експлоатацији дрвних ресурса која не нарушава еколошки екосистем. ${ }^{38}$

Афирмација инклузивної и оgрживої развоја би требало да осигура социо-економски развој који пружа услове за достојанствени рад и једнаке радне могућности свим слојевима становништва. Ово се нарочито односи на запошљавање младих и креирање нових занимања у високопродуктивним секторима (нпр. креативним индустријама, ИТ сектору и сл.). Развој креативних индустрија и подстицање креативног предузетништва могу унапредити иновације, раст микро и малих организација, а комбинацијом нових технолошких решења може се креирати висока додата вредност и продуктивност. Библиотеке могу помоћи члановима локалне заједнице у приступу информацијама ради проналажења посла, али и унапређењу знања и пословних вештина. Тако, на пример, у Румунији око 35 руралних библиотека, у сарадњи са партнерима из невладиног сектора, спроводи програм CODE Kids намењен учењу кодирања код деце узраста 10-14 година. Циљ програма је да мотивише младе да више времена проводе у едукацији на интернету, подстакне их да размишљају о ИТ каријери и стекну основна знања о кодирању, која им могу помоћи у даљем образовању у овој области. ${ }^{39}$ Инклузивни развој

\footnotetext{
${ }^{35}$ M. Gaffet and C. Espy, "The Role of National Libraries in Contributing Towards the Sustainable Development goal of Gender Equality" (paper presented at IFLA WLIC 2016 - Columbus, OH - Connections. Collaboration. Community), preuzeto 1. 7. 2018, http://library. ifla.org/1487/2/115-gaffet-en.pdf.

${ }^{36}$ READ Information and Resource Centre, preuzeto 1. 7. 2018, http://readglobal.org/our-work/read-nepal.

37 Видети: Beyond Access, Public Libraries Power Development, preuzeto 1. 7. 2018, http://beyondacess.net.

${ }^{38}$ Ibid.

${ }^{39}$ О пројекту CODE Kids видети више: Code kids - Coding for Kids in Libraries, preuzeto 1. 7. 2018, http://www.progressfoundation.ro/ coding-3/.
} 
подразумева и укључивање маргинализованих група у друштвена дешавања и повећање њихових шанси за достојанствен живот. Загребачка градска библиотека спроводи програм намењен бескућницима како би повећала њихово самопоуздање, смањила препреке у тражењу посла и помогла њиховом друштвеном оснаживању. Кроз радионице, јавне часове и тренинге омогућава им стицање дигиталне писмености и пружа помоћ у претраживању информација за посао и ствара предуслове да се поново повежу са заједницом у којој живе. ${ }^{40}$

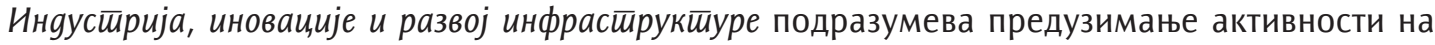
пољу истраживања и развоја, информационо-комуникационих технологија и приступа интернету. Оспособљавање за дигитално предузетништво и боља повезаност дигиталне економије и традиционалних сектора може допринети трансферу технологије, знања и пословних модела те дугорочно утицати на економски раст (и развој). Тако, на пример, библиотеке могу постати нова места развоја заједнице и искорачити из традиционалне улоге установа које развијају само читалачке навике, већ нудити већи број културних програма и стварати нове навике локалног становништва. Иновативне и предузетнички оријентисане библиотеке попут МiamiDade Public Library System или Spokane Public Library у Вашингтону иду корак даље у иновацијама и развоју инфраструктуре за предузетништво. Ове библиотеке су редизајнирале своје просторе како би се трансформисале у co-working заједницу релевантну за ИТ предузетнике, дигиталне номаде и оне који раде у креативним делатностима. ${ }^{41}$ Осим места за рад, оне нуде савремену ИТ инфраструктуру и приступ лиценцираним софтверима за дизајн, архитектуру, моделовање, анимације и сл., као и информације о тржишту хартија од вредности и трговању на њему, финансијске анализе и економске пројекције.

Смањење нејеgнакости подразумева стварање услова у којима постоје једнаке економске, социјалне и политичке могућности за све појединце, независно од њихове старости, пола, здравствених способности, етичке припадности, економског статуса и сл. Култура у остваривању овог циља има двоструку улогу. Елементи културе, разноликост културних израза, специфични културни кодови могу бити основа за развој креативног предузетништва маргинализованих група. ${ }^{42}$ Међутим, да би предузетничке идеје постале одрживи послови, библиотеке могу послужити као бизнис инкубатори за самосталне предузетнике, студенте, особе које траже послове или хонорарне креативце. Тако на пример, Akron-Summit County Public Library Microbusiness Center у Акрону пружа услуге двогодишњег програма пословне инкубације за почетнике у бизнису различитих профила (креативне индустрије, уметничко предузетништво, одржива пољопривреда, дигиталне услуге и маркетинг и сл.), пружа им тренинге у области предузетништва, руковођење предузетничким подухватом, као и правне и административне услуге. ${ }^{43}$

Оgрживи іраgови и оgрживе зајеgниие подразумева стварање градова који су сигурни, прилагодљиви и одрживи. У остваривању овог циља потребно је обезбедити сигурно и приступачно становање, ефикасан јавни превоз, довољан број зелених површина, партиципативно урбанистичко планирање, заштиту природног и културног наслеђа и сл. Култура има више функција у стварању одрживих градова. Она је важна за идентитет града, његову урбану регенерацију, али и као простор за дијалог и размену идеја. Библиотеке могу бити покретачи урбане обнове на различите начине. Као иконичке грађевине које креирају идентитет места (нпр. Библитека Alexandrina у Александрији и Seattle Public Library у Сијетлу), као актери унапређења

\footnotetext{
${ }^{40}$ Tportal.hr, Knjigom do krova: mreža knjižnica za osnaživanje beskućnika, (Zagreb, 2011), preuzeto 1. 7. 2018, https://www.tportal.hr/ kultura/clanak/zagrebacke-knjiznice-beskucnicima-nude-novu-sansu-20111114.

${ }^{41}$ Видети: Libraries as Co-working Spaces, preuzeto 1. 7. 2018, http://www.techsoupforlibraries.org/blog/libraries-as-co-working-spaces.

42 Видети на пример истраживање о креативном предузетништву Рома у Пироту. Х. Микић, Е. Радоњић-Живков и љ. Димитријевић,

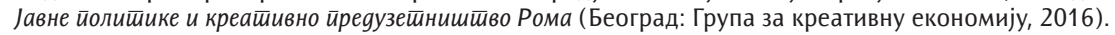

${ }^{43}$ Више видети: С. Jahnson, 5 Coworking Spaces and Business Incubators in Libraries that Support Local Workers (Sharable, 2017), preuzeto 1. 7. 2018, https://www.shareable.net/blog/5-coworking-spaces-and-business-incubators-in-libraries-that-support-local-workers.
} 
виталности заједнице (нпр. Garaget у Малмеу) или као креатори идентитета одређених просторних целина (нпр. Градска библиотека у Ванкуверу, Bibliotheek Amsterdam). ${ }^{44}$

Еколошки изазови и очување живошине среgине представљаји важан аспект у остваривању одрживог развоја. Њима је намењено неколико циљева - од оних који су посвећени одговорној потрошњи ресурса и производњи, климатским променама, одрживом подводном свету, управљању рекама, биодиверзитетом и заштити водених ресурса, до заштите природних ресурса, земљишта и очувању биодиверзитета. Cyberiada Public Library у Пољској развила је интерактиви образовни програм о екологији. Скоро 2000 деце, користећи таблете и интерактивне видео-игре, уче о енергији, заштити вода, рециклажи, биодиверзитету и сл., а на основу стеченог знања и сама покрећу микро-еколошке пројекте. ${ }^{45}$

Промоција мира и иравеgної gруштева односи се на изградњу праведног и мирољубивог друштва. Сузбијање организованог криминала, смањење корупције и илегалних токова новца требало би да води стварању одговорних и транспарентних институција. Упознавање других култура и њихових достигнућа омогућава интеркултуралну комуникацију и ненасилно друштво. Mobile Public Libraries Project је иницијатива у Колумбији коју су покренули Министарство културе, национална библиотека и мрежа јавних колумбијских библиотека. Циљ програма је да се изгради култура мира у пост-конфликтним подручјима у којима су се одвијали сукоби између владе, герилских група и паравојних формација од 1964. године. Мобилне библиотеке за мир постављене су на 20 места у зонама примирја, које су дефинисане мировним споразумом као места демобилизације и разоружања герилских група. Њихова улога је да омогуће становништву у овим зонама приступ информацијама и да допринесу изградњи мира кроз боље разумевање узрока конфликта, промовисање дијалога између сукобљених страна и омогуће интеграцију припадника герилских група у цивилни живот. ${ }^{46}$

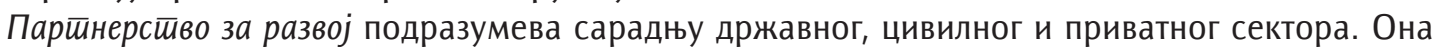
може бити на различитим нивоима - локална, регионална, национална, међудржавна и глобална. Култура је најснажније средство подстицања међународне сарадње и дијалога међу народима, али и тема око које се могу градити различита партнерства како на локалном, тако и на регионалном нивоу. На пример, сарадња аутомобилске индустрије у Италији, установа заштите, музеја, архива, библиотека, туристичких организација, невладиних организација и грађана синергијским деловањем су подстакли развој одрживог културног туризма, као и заштиту индустријског наслеђа у региону Модене. Кроз пројекат стварања кластера аутомобилске индустрије креирани су услови за сарадњу установа културе, привреде и државних органа како би се унапредила регионална конкурентност кроз индустријско наслеђе и креирао нови културни живот. ${ }^{47}$

\section{Закључак}

Агенда одрживог развоја 2030 представља глобални оквир за постизање праведније расподеле ресурса и смањење економских разлика између богатих и сиромашних земаља. Иако у овом стратешком документу култура није заступљена кроз експлицитни циљ, она има третман међусекторске области. Тиме је њена улога у постизању одрживог развоја шира - она није ограничена само на доступност културних садржаја и партиципацију у културним активностима, већ постаје компонента свих друштвених области - од сиромаштва, здравствених потреба,

\footnotetext{
${ }^{44}$ C. Hvenegaard Rasmussen et al., "The Role of Public Libraries in Urban Development and Culture-led Regeneration", (paper presented at European Public Libraries Today and in an Historical Context, Norway, Oslo, 9-10 December 2010).

${ }^{45}$ K. Nicholson, Innovation in Public Libraries: Learning from International Library Practice (Kidlington: Elsevier, 2017 ), 43.

${ }^{46}$ Видети више: Library Map of the World, Mobile Libraries for Peace, (2017), preuzeto 1. 7. 2018, http://librarymap.ifla.org/stories/ Colombia/MOBILE-LIBRARIES-FOR-PEACE/19.

${ }^{47}$ A. Fernando and G. Jessica," Cultural Heritage, Tourism and Regional Competitivness: The Motor Valley Claster", City, Culture and Society 3 (2012): 261-273.
} 
образовања до промоције мира и праведног друштва. Улога библиотека у остваривању ових циљева је више него значајна. Библиотечки пилот-пројекти остваривања циљева одрживог развоја доприносе да се примери добре праксе мултипликују и шире кроз систем библиотека. Ипак, у националним политикама појединих земаља (где спада и наша) библиотеке нису идентификоване као важни актери реализације циљева одрживог развоја. 3бог тога је важно да се препознају многоструке улоге библиотека у националним статегијама и програмима развоја културе и допринесе бољем коришћењу потенцијала које библиотечке установе поседују у остваривању одрживог развоја.

\section{Литература и извори:}

1. Beyond Access. Public Libraries Power Development. Preuzeto 1. 7. 2018. http://beyondacess.net.

2. Code kids - Coding for Kids in Libraries. Preuzeto 1. 7. 2018. http://www.progressfoundation.ro/coding-3/.

3. Crnković, Vesna. „Seoske biblioteke u funkciji podizanja preduzetničkih kapaciteta - primer projekta Poljoprivredne biblioteke“. Izlaganje na 2. Školi kreativne ekonomije. Niš: Grupa za kreativnu ekonomiju, 2016.

4. Fernando, A. and G. Jessica." Cultural Heritage, Tourism and Regional Competitivness: The Motor Valley Claster". City, Culture and Society 3 (2012): 261-273.

5. Forsyth, E. "Public Libraries and the Millennium Development Goals". IFLA Journal 31, 4 (2005): 315-323.

6. Fried, S. et al. "A Tale of Public Libraries in Bulgaria, Poland and Romania: The Case of Three Gates Foundation Grants". Library Trends (Fall 2014): 127-143.

7. Gaffet, M. and C. Espy. "The Role of National Libraries in Contributing Towards the Sustainable Development Goal of Gender Equality". Paper presented at IFLA WLIC 2016 - Columbus, OH Connections. Collaboration. Community. Preuzeto 1. 7. 2018. http://library.ifla.org/1487/2/115gaffet-en.pdf.

8. Global Network of Cities, Local and Regional Governments. Preuzeto 1. 7. 2018. http://www. agenda21culture.net/advocacy/culture-as-a-goal-in-post-2015.

9. Hvenegaard Rasmussen, C. et al. "The Role of Public Libraries in Urban Development and Cultureled Regeneration". Paper presented at European Public Libraries Today and in an Historical Context, Norway, Oslo, 9-10 December 2010.

10. IFLA. "The Role of Public Libraries in the Attainment of Botswana's Vision 2016". Preuzeto 1. 7. 2018 http://library.ifla.org/258/1/201-radijeng-en.pdf.

11. Jahnson, C. 5 Coworking Spaces and Business Incubators in Libraries that support local workers. Sharable, 2017. Preuzeto 1. 7. 2018. https://www.shareable.net/ blog/5-coworking-spaces-and-business-incubators-in-libraries-that-support-local-workers.

12. Krolak, L. "The Role of Libraries in the Creation of Literate Environments". IFLA, 2005. Preuzeto 1. 7. 2018. https://www.ifla.org/files/assets/literacy-and-reading/publications/role-of-libraries-in-creationof-literate-environments.pdf.

13. Kuzmanović, J. „Nova uloga biblioteke u osnovnim školama i komunikaciona strategija za njeno promovisanje". Kultura polisa br. 17 (2012): 123-146.

14. Libraries as Co-working Spaces. Preuzeto 1. 7. 2018. http://www.techsoupforlibraries.org/blog/ libraries-as-co-working-spaces.

15. Library Map of the World. Mobile Libraries for Peace. 2017. Preuzeto 1. 7. 2018, http://librarymap. ifla.org/stories/Colombia/MOBILE-LIBRARIES-FOR-PEACE/19.

16. Lipeikaite, U. and G. Oyarzun. Agriculture, Libraries and Human Development: Case Studies of Europe, Africa and Latin America. Singapore: IFLA WLIC, 2013. Preuzeto 1. 7. 2018. http://library.ifla. org/115/1/141-lipeikaite-en.pdf. 
17. Mikić, H. „Ekonomske pretpostavke i razvojni efekti kreativnog sektora nacionalne privrede“. Doktorska dis., Ekonomski fakultet, 2016.

18. Mikić, H., E. Radonjić-Živkov i Lj. Dimitrijević. Javne politike i kreativno preduzetništvo Roma. Beograd: Grupa za kreativnu ekonomiju, 2016.

19. Nicholson, K. Innovation in Public Libraries: Learning from International Library Practice. Kidlington: Elsevier, 2017.

20. Opaku, A. "The Role of Culture in a Sustanible Built Environment". In Sustainable Operations Management. Edited by A. Chiarini, 37-52. Cham: Springer, 2015.

21. READ Information and Resource Centre. Preuzeto 1. 7. 2018. http://readglobal.org/our-work/ read-nepal.

22. Ramotswa Public Library, Sesigo Libraries, Botswana. Preuzeto 1. 7. 2018. http://www.sesigo.org. bw/index.php?id=49.

23. SeCons. Preuzeto 1. 7. 2018. http://www.ciljeviodrzivograzvoja.net.

24. Shan, P. and G. Abhishek. Digital Libraries for the Poor. Washington: World Bank, 2014. Preuzeto 1. 7. 2018. http://blogs.worldbank.org/endpovertyinsouthasia/digital-libraries-poor.

25. Throsby, D. "Culture in Sustainable Development: Insights for the Future Implementation of Art 13". Preuzeto 5. 7. 2018. http://unesdoc.unesco.org/images/0015/001572/157287E.pdf.

26. Throsby, D. Economics and Culture. Cambridge: Cambridge University Press, 2001.

27. Tportal.hr. Knjigom do krova: mreža knjižnica za osnaživanje beskućnika. Zagreb, 2011. Preuzeto 1. 7. 2018. https://www.tportal.hr/kultura/clanak/ zagrebacke-knjiznice-beskucnicima-nude-novu-sansu-20111114.

28. UCLG. "Culture: Fourth Pillar of Sustainable Development". Committee on Culture for 2011-2013. Preuzeto 1. 7. 2018. http://www.agen-da21 culture.net/docs_circulars/ECOSOC2013Committeeonculture-ENG.pdf.

29. Uhegbu, A. and I. Igwe. "Information and Communication Technology (I.C.T) and the Millennium Development Goals". Information Technologist 3: 2 (2006): 97-109.

30. Ujedinjene nacije. Univerzalna deklaracija o ljudskim pravima. UN, 1948.

31. UN Ekonomski i socijalni savet. Zaključne primdbe o drugom periodičnom izveštaju Srbije. UN Ekonomski i socijalni savet, 23. maj 2014. Preuzeto 1. 7. 2018. http://www.rwfund.org/wp-content/ uploads/2014/12/Ekonomski-i-socijalni-savet-UN-Komitet-za-ekonomska-socijalna-i-kulturna-prava. pdf.

32. UN General Assembly. Resolution Adopted by the General Assembly - 57/249. Culture and Development, 57/249. New York: UN, 2003.

33. UN General Assembly. Resolution on Culture and Development A/C.2/65/L.50. New York: UN, 2010.

34. UN General Assembly. Resolution on Culture and Sustainable Development A/C8/440/add.4. New York: UN, 2013.

35. UN Generalna skupština. Međunarodni pakt o ekonomskim, socijalnim i kulturnim pravima. UN Generalna skupština, 1966. Preuzeto 1. 7. 2018. http://www.unmikonline.org/regulations/ unmikgazette/05bosniak/BIntCovEcSocCulRights.pdf.

36. UN World Commission on Environment and Development. Report on the World Commission on Environment and Development: Our Common Future. New York: United Nations -World Commission on Environment and Development, 1987. Preuzeto 1. 7. 2018. http://www.un-documents.net/ourcommon-future.pdf.

37. UN. "United Nations Millennium Declaration", 55/2. United Nations, 2000. Preuzeto 1. 7. 2018 https://www.un.org/millennium/declaration/ares552e.htm.

38. UN. Transforming Our World: the 2030 Agenda for Sustainable Development, A/RES/70/1. New York: UN, 2015.

39. UNESCO. Cultural Diversity, Conflicts and Pluralism. Paris: UNESCO, 2000.

40. UNESCO. Culture for the 2030 Agenda. Paris: UNESCO, 2018. Preuzeto 1. 7. 2018. http://unesdoc. unesco.org/images/0026/002646/264687e.pdf. 
41. UNESCO. Culture, Creativity and Markets. Paris: UNESCO, 1998.

42. UNESCO. Florence Declaration Outlines Recommendations on Culture for Post-2015 Agenda: Culture, Creativity and Sustainable Development. Research, Innovation, Opportunities. Florence: UNESCO, 2014.

43. UNESCO. Hangzhou Declaration Placing Culture at the Heart of Sustainable Development Policies. Paris: UNESCO, 2013.

44. UNESCO. Our Creative Diversity. Paris: UNESCO, 1996. Preuzeto 1. 7. 2018. http://unesdoc.unesco.org/ images/0010/001055/105586e.pdf.

45. UNESCO. UNESCO Moving Forward the 2030. Agenda for Sustanible Development. Paris: UNESCO, 2017.

Preuzeto 1. 7. 2018. http://unesdoc.unesco.org/images/0024/002477/247785e.pdf.

46. World Bank. Fostering a Digitally Inclusive Aging Society in China: the Potential of Public Libraries.

Washington: World Bank, 2014.

\section{Culture and Sustainable Development Agenda 2030}

\section{Summary}

The UN 2030 Agenda was adopted in 2015. The Agenda consists of 17 goals and 169 specific activities and results that would be achieved through its implementation. The Agenda does not address explicitly the issues of culture within sustainable development. In certain goals, its contribution is emphasized in the field of education and economic empowerment through cultural tourism. In the introduction of this document, culture is mentioned in only one paragraph, through the declarative confirmation of the importance of natural and cultural diversity, and their contribution and the key role in sustainable development. The Agenda deals with culture in three goals. Culture is mentioned as a component of education that promotes sustainable development (goal 4), a resource for the development of sustainable tourism (goal 8), and a way for making cities and human settlements inclusive, safe, resilient and sustainable, by strengthening efforts to protect and safeguard the world's cultural and natural heritage (goal 11). There are a lot of critics of the weak position of culture in the sustainable development goals and this situation can be seen as a weakness of the Agenda. But a careful analysis of the Agenda has shown that culture is treated as an intersectoral field in the global goals of sustainable development. Operational guidelines for the implementation of the Agenda show that culture and creative entrepreneurship are viewed as a horizontal issue of public policies, which is not limited to specific objectives, but is one of the dimensions of global development processes.

This paper deals with the role of culture in achievement of the UN sustainable development goals until 2030. The first part of the paper provides a theoretical framework for exploring interconnections between culture and sustainable development. The second part is dedicated to the review of the UN activities in the field of culture. The last part of the paper is focused on the role of culture in the UN Agenda for sustainable development 2030, with special focus on libraries.

Keywords: culture, United Nations, sustainable development, libraries, UN Agenda 2030, UNESCO 


\section{(2) $(\Theta \Theta$}

Култура и Агенда одрживог развоја 2030 bу Христина Микић is licensed under a Creative Commons Attribution-NonCommercial-NoDerivatives 4.0 International License. 